\title{
Beyond the Trenches: Ol'ha Kobylians'ka's Literary Response to the First World War
}

\author{
Yuliya Ladygina \\ Sewanee: The University of the South, TN
}

\begin{abstract}
Ol'ha Kobylians'ka's short stories about the First World War constitute a rare case of a Ukrainian woman writing on one of the greatest catastrophes in modern history, a subject neglected even in Ukraine. Drawing on recent scholarship on First World War literature, this research proves that Kobylians'ka's war stories deserve a re-evaluation, not as long-ignored curiosities from the pen of Ukraine's most sophisticated writer of the time, but as insightful psychological studies of Western Ukrainians and as valuable cultural documents that present an original perspective on the common European experience of 1914-1918. The article pays particular attention to Kobylians'ka's creative assessment of the Austrian and Russian treatment of Western Ukrainians during different stages of the First World War, which exposes anew fatal political weaknesses in Europe's old imperial order and facilitates a better understanding of why Ukrainians, like many other ethnic groups in Europe without a state of their own, began to pursue their national goals more aggressively as the war progressed. Alongside popular texts, such as "Na zustrich doli" ("To Meet Their Fate," 1917), "Iuda" ("Judas," 1917), and "Lyst zasudzhenoho voiaka do svoiei zhinky" ("A Letter from a Convicted Soldier to His Wife," 1917), this article examines Kobylians'ka's three little-known stories"Lisova maty" ("The Forest Mother," 1915), "Shchyra liubov" ("Sincere Love," 1916), and "Vasylka" ("Vasylka," 1922)-thus presenting the most complete analysis of Kobylians'ka's war fiction in any language.
\end{abstract}

Keywords: Modernist Literature, Literature of the First World War, Women Writings of the First World War, Ol'ha Kobylians'ka's War Fiction

The First World War, with its associated social and political changes, provided an experience, an object of reflection, and a mixture of powerful emotions that forced the generation of the fin-de-siècle European intellectuals to revise entirely their prewar beliefs. The revision, in turn, inspired an outpouring of fiction, memoirs, and writing on ideology, culture, aesthetics, and the role of the intellectual in the reconstruction of Europe. Post-1918 scholars have produced an equally plentiful, varied, and, frequently, contradictory body of critical works, keeping the catastrophic events of 1914-1918 firmly present in the mind and memory of later generations. Until recently, however, the critical attention of Western scholars has focused exclusively on the works of male authors, such as 
Henri Barbusse, Robert Graves, Erich Maria Remarque, and Siegfried Sassoon. Paul Fussell's The Great War and Modern Memory (1975), which remains the most frequently cited study on the literature of the First World War, provides a telling example. Fortunately, large-scale scholarly projects of recent decades have begun to retrieve and analyze the experience of women, bringing attention to the neglected corpus of women's literary responses to one of the greatest catastrophes in modern history. Authoritative and noteworthy contributions, such as Sandra Gilbert's and Susan Gubar's No Man's Land (1988), Claire Tylee's The Great War and Women's Consciousness (1990), Sharon Ouditt's Fighting Forces, Writing Women (1994), and Jane Potter's Boys in Khaki, Girls in Print (2005), have filled the conspicuous void left by Fussell and others, moving the designation of war literature beyond the battlefield to include creative accounts by anyone - soldier or civilian, man or woman - who struggled to express the unthinkable horrors of war. Building on recent scholarship dealing with the First World War, this article explores a new area of research by analyzing war narratives written by Ol'ha Kobylians'ka (18631942), one of Ukraine's most sophisticated modernist prose writer, who represents a rare and little known case of a Ukrainian woman writing about the First World War on the Eastern Front.

Kobylians'ka and her work have received sustained attentionscholarly and critical, panegyric and polemical, propagandistic and ideological-however, her literary response to the First World War remains barely discussed, let alone properly researched and contextualized. Early on, Soviet censorship found the pro-Austrian rhetoric and pronounced antiRussian sentiments in some of Kobylians'ka's war stories unfit for the Soviet context and banned them from publication. ${ }^{1}$ As a result, Kobylians'ka's war fiction has received little critical attention. On the few occasions when the stories appear in scholarly discussions, their ideological statements are typically dismissed as mere opportunistic oratory (Tomashuk 179-180; Mel'nychuk 6,121) or a critique of the uneducated peasant mind (Babyshkin 171-72; Pavlyshyn 247-48), and the complete body of Kobylians'ka's writings of the First World War is usually read as a single artistic and ideological entity (Vasylenko 85; Babyshkin 171-74; Pavlyshyn 244), a so-called "novel in novelettes" (Mel'nychuk 109) held together by its antiwar rhetoric. ${ }^{2}$ However, such a unifying reading proves

\footnotetext{
1 "Lisova maty" and "Vasylka," Kobylianska's two war stories with strongest proAustrian undertones, were last published in 1929 in the second volume of the first Soviet edition of Kobylians'ka's collected works in nine volumes (Lyzanivs'kyi).

2 Vasyl' Lesyn was first to read Kobylians'ka's short prose works set in the First World War as a unified antiwar cycle in his 1958 article "Antyvoienni tvory Ol'hy
} 
problematic once we examine the thematic, ideological, and stylistic particularities of Kobylians'ka's war stories, which fall into several distinct cycles separated not only by time, but also by the different claims they made on contemporary readers' attention. The stories silenced by Soviet censors prove particularly revealing. Not only do they testify to the writer's continuous search for, and experimentations with, the rhetorical possibilities for expressing the unspeakable brutality of war, which she experienced firsthand during Russia's three occupations of Bukovyna between 1914 and 1917, but they also register a gradual evolution in the writer's views on loyalty, civic duty, and national identity, as well as her simultaneous transformation from a pro-Austrian loyalist to a supporter of Ukraine's political independence. ${ }^{3}$ Furthermore, a close reading of popular texts, such as "Na zustrich doli" ("To Meet Their Fate," 1917), "Iuda" ("Judas," 1917), and "Lyst zasudzhenoho voiaka do svoiei zhinky" ("A Letter from a Convicted Soldier to His Wife," 1917), alongside works virtually unknown to readers and scholars of Ukrainian literature- "Lisova maty" ("The Forest Mother," 1915), "Shchyra liubov" ("Sincere Love," 1916), and "Vasylka" ("Vasylka," 1922)—proves that Kobylians'ka's war writings deserve a reexamination both as astute psychological profiles of Western Ukrainians struggling with multiple loyalties during the First World War, and as a means to imagine the collective experience of 1914-1918 anew.

FIRST LITERARY RESPONSES, 1914-1915

Although the fifty-year-old Kobylians'ka suffered serious illness, financial ruin, and deep depression at the outbreak of the First World War, her first war narratives, "The Forest Mother" and "Sincere Love," display the same poignancy and ideological complexity as her earlier works." The most noteworthy aspect of Kobylians'ka's first war stories is their somewhat

Kobylians'koi" (Lesyn, Slyn'ko, and Cherednychenko, 1958). Oleh Babyshkin, Nykyfor Tomashuk and Fedir Pohrebennyk, the major Soviet scholars of Kobylians'ka's works, supported Lesyn's reading, influencing subsequent postSoviet scholars of Kobylians'ka's late fiction (Babyshkin 1963; Tomashuk 1969; Pohrebennyk 1983).

${ }^{3}$ For a discussion of Kobylians'ka's prewar political loyalties and her views on the Ukrainian national cause, see Pavlyshyn 229-43.

${ }^{4}$ Kobylians'ka's 1913 letter to Khrystia Alchevs'ka is the best-known testimony of her prewar depression. See Komychanchenko 5: 618. For further discussion, see Vozniuk 147-53. 
jingoistic pro-Austrian rhetoric, which many scholars read as problematic and irrelevant to the Ukrainian national project of the day. As a result, a variety of apologetic narratives, each tailored to a specific ideological framework, from socialist to neo-patriotic and revisionist, has arisen over the past century to justify Kobylians'ka's Austrophilism (Babyshkin 171-74; Tymoschuk 179-81; Mel'nychuk 121; Demchenko 174-78). However, the contemporary scholarship on the complex system of multiple loyalties held by Ukrainian subjects of the Habsburg Empire at the turn of the nineteenth century (Himka 3-12; Magocsi 73-82; Subtelny 307-35; Snyder 95-148) problematizes such apologies, suggesting an alternate reading of Kobylians'ka's pro-Austrian sentiments.

As historians have shown, Galician and Bukovynian Ukrainians were among the most ardent of Austria's many nationalities in their loyalty to the Habsburg Empire-from the empire's beginning in 1772 until its dissolution in 1918, and even beyond. Ukrainian loyalty reflected a genuine appreciation of the religious, economic, and political gains Ukrainians achieved under Austrian rule (Magocsi 73-82; Subtelny 307-35). For example, in 1774 Emperor Joseph II granted the Ukrainian Greek Catholic Church legal equality with the Roman Catholic Church, which led to positive changes in Ukrainian cultural and political life. In 1848, the Austrian government abolished serfdom and freed the Ukrainian peasantry, which substantially improved its economic situation. In addition, Emperor Franz Joseph established a new Austrian parliament in 1861 that gave Ukrainian secular leaders an opportunity to join the Austrian intellectual and political elite, which bolstered the growth of Ukrainian civil society. These reforms, along with the social and cultural changes they instigated, caused a significant percentage of the Western Ukrainian intelligentsia and peasantry to see Austria as "their legitimate homeland" and to regard their Habsburg rulers as "benevolent father figures" (Magocsi 73, 77). As the tragic events of the First World War show, expressions of Ukrainian gratitude were not limited to rhetoric alone: almost 250,000 Ukrainians fought bravely in various branches of the Austrian imperial army during the war. It is also worth noting that, despite the repressive nature of AustroHungarian wartime rule in Galicia and Bukovyna, on the occasions when Austro-Hungarian troops retook the provinces from the Russian army, many Western Ukrainians maintained loyalty to the Habsburg dynasty even after the empire's collapse in 1918-in hopes of its reincarnation (Magocsi 77-78; Snyder 95-148). ${ }^{5}$ This historical context clearly calls for a thorough

\footnotetext{
${ }^{5}$ When the advancing Russian army broke through Austrian defenses and occupied much of Eastern Galicia and Bukovyna in the first months of the war, the Austrian setback had terrible repercussions for the local Ukrainians. The Ukrainians were
} 
reconsideration of Kobylians'ka's pro-Austrian rhetoric in her early war stories.

The symbolic and stylistic particularities of "The Forest Mother" and "Sincere Love" also suggest that Kobylians'ka views her Habsburgtreu (loyal-to-the-Hapsburgs), or more precisely Kaisertreu (loyal-to-theemperor), peasant characters with more sympathy and fascination than earlier scholars argued (Babyshkin 172; Tymoschuk 179-81; Pavlyshyn 247). In "The Forest Mother," for example, Kobylians'ka uses stylistic devices to assert the exceptional insight and sense of belonging of her heroine, the old Hutsul Dokiia, ${ }^{6}$ who develops an attachment to the monarchy so deep that she is able, with dignity and even equanimity, to part with her only son, who has been called to fight in the war. Although Dokiia lacks a formal education and is detached from the political debates in Europe, she possesses an acute understanding of her own existence, placing it in the broader context of such historical events as the 1898 assassination of the last Hapsburg empress Elisabeth of Austria and the 1914 outbreak of the First World War. Following the nineteenth-century models of psychological realism, Kobylians'ka intercuts realistic depictions of Dokiia's primitive daily life with her internal dialogues, which present a vibrant picture of the heroine's cognitive and emotional life, continually disrupting and thus subverting the overall doom-and-gloom tone of the story. Dokiia's own associations between forest and her "whole region" (tsil[yi] kra[i]) (60) - that is, a broader community, perhaps as broad as the entire empire, to which she belongs- which the old woman constructs while pondering her place in the world, complicate her devotion to the Hapsburg crown, framing the Austrian empire as an extended family formed of members who are heterogeneous yet intimately connected to one another. The "forest mother" - the ancient pine tree in the nearby forest that Dokiia associates with the Empress Elisabeth-is the key image in the chain of associations that establishes a coherence between nature, the Habsburg family, and their imperial subjects.

Dokiia's personalized conception of the empire brings to mind important studies on group psychology of the time, hinting at what we

often accused of treason and were either executed without a trial or sent by the thousands to concentration camps. For further discussion of Austro-Hungarian wartime repressions in Galicia and Bukovyna, see Subtelny 341; Bryndzan et al. 296-301; and Karpynets' et al. 60-67.

${ }^{6}$ Hutsuls are a dominant Ukrainian ethnic group living in the Carpathian Mountains. At the turn of the nineteenth century, Hutsuls were predominantly peasants. 
might compare to Freud's libidinal explanation of group psychology. In a 1922 study, Freud positions libido, that is, the totality of "instincts, which have to do with all that may be comprised under the word of love," as the key psychological bond cementing a group together (Freud 29). Freud places eroticism at the nucleus of his concept of love, but he does not exclude other manifestations of love-on the one hand, self-love, and, on the other, love for family, friends, or humanity in general, along with devotion to concrete objects and abstract ideas-from his discussion. He particularly emphasizes the importance of a leader, who poses as the ideal father figure, in the psychology of the group. Libidinal ties and selfidentification with the group's leader, Freud observes, bind individual members of any socially constructed group to each other (Freud 46-68). Accordingly, Kobylians'ka's representation of Dokiia's deep devotion to the Habsburg empress can be read as the writer's inquiry into the nature of the pro-Austrian loyalty of Western Ukrainians at the outbreak of the First World War.

"The Forest Mother" opens with a mystical paragraph, which sets the story in the distant wonderland of Bukovyna populated by spirits, mermaids, and enchanted children of the Carpathian Mountains, whose wits are often bewitched by magic herbs (54). ${ }^{7}$ This introduction instantly transports the reader into the enchanted world in Mykhailo Kotsiubyns'kyi's celebrated novel Tini zabutykh predkiv (Shadows of Forgotten Ancestors, 1911) and evokes the mood in Kobylians'ka's earlier "rustic" works, a mood which combines sincere admiration of the Hutsuls' authentic spirit with a sharp anti-populist criticism of their primitive mentality and superstitious beliefs. ${ }^{8}$ Admittedly, these intertextual references could be read as Kobylians'ka's critique of Dokiia's simple mind, yet the heroine's powerful flashback to her enlightening experience with a visiting village teacher leaves no room for such a reading. Immediately after the story's introduction, the reader meets Dokiia who, while gathering wood and contemplating the natural beauty of the pristine forest, confesses that "there used to be a time when she [Dokiia] did not notice and did not understand any of it" (56), implying a profound cognitive transformation in her past. The heroine credits the teacher for instructing her in how to interpret and to relate to the surrounding world, as well as for encouraging

\footnotetext{
${ }^{7}$ All translations of Kobylians'ka's war stories are mine. Therefore, all citations of Kobylians'ka's texts in this article refer to Ukrainian originals.

8 Ol'ha Kobylians'ka's short stories "Pryroda" ("Nature," 1895) and "Nekul'turna" ("Uncultured," 1897), as well as her two novels Zemlia (The Earth, 1902) and $V$ nediliu rano zillia kopala (On Sunday Morning She Gathered Herbs, 1909), are the best examples.
} 
her to think critically and to reflect on philosophical questions, such as "where does longing come from and where does it go?" (56). Later in the story, we also learn that the teacher's allegorical parallels between the human condition and life in the forest form the foundation of Dokiia's personalized conception of the world, which illuminates the psychological mechanisms of her Habsburgtreu attitude, presenting it as a wellsubstantiated and long-term sentiment.

The most powerful representations of the heroine's pro-Austrian loyalty appear in the two final scenes of the story, which feature Dokiia's emotional response to the 1898 assassination of Elisabeth of Austria and the 1914 outbreak of the First World War. In both cases, Kobylians'ka uses dialogue to capture Dokiia's internal world in its most raw state. The first exchange takes place between the old Hutsul woman and the local priest, to whom she offers all of her life savings to say a Mass for the repose of the empress's soul. In this scene, the priest merely facilitates Dokiia's confession:

Here it is, father. I have been saving and putting away money for a long time, and now I have five kronen. Don't be angry, take it, father, take it. Don't despise it. I give it with love. I saved it for my funeral and stored it secretly in my pantry. Even my own child did not know about it. My only child... Take it... This is for her, for the empress, to hold a service for her, for our mother! Oh, father! She was the mother of the whole land and such a mother has been killed! Won't Jesus come down from heaven and avenge her? He will do so. (61)

The fragmented nature of Dokiia's speech not only amplifies the heroine's distress but also provides insight into her thought process, revealing her profound psychological connection to the assassinated empress, whom she sees as an ideal mother, an abstraction of the fatherland, peace, and prosperity, and whose loss she symbolically links to her own death. By highlighting that she is not alone in treating the empress as a maternal figure, the heroine links her sorrow to the deep mourning experienced by the entire Austro-Hungarian nation, asserting her membership in a broader community. The priest's admiration for Dokiia's sincere offering endorses her call for just vengeance, and his sympathy for her emotional state further guides the reader to see Dokiia not as a poor, insignificant peasant, "lost in the deep woods" (61), but as a compassionate and devoted community member, who inspires empathy rather than reproach.

Dokiia's loyalty to the Habsburg crown is further complicated in the closing scene, which evokes the Biblical story of the Binding of Isaac, reinforcing the reader's fascination with the old Hutsul Woman's genuine patriotism. The abrupt shift from the 1898 episode with the priest to the 
1914 scene with Dokiia's son Iurko, whom the heroine sees off to the imperial army, brings the two fragments together, symbolically connecting the assassination of a Habsburg with the outbreak of the First World War, and presenting Dokiia's son as another sincere and conscious sacrifice she makes to the imperial family. Dokiia's last conversation with her son is terse yet emotionally charged. As is suggested by the narrator's commentary, both characters understand the grim prospects of Iurko's military service, realizing that the ongoing conversation might be their last. Yet both demonstrate exemplary self-control, accepting their civic duty with dignity.

Dokiia's successful resolution of the profoundly painful struggle between her maternal love and her loyalty to the Habsburgs proves especially striking when we compare the final scene of "The Forest Mother" to a similar episode in Kobylians'ka's 1923 short story "Vovchykha" ("The She-Wolf"). Whereas Zoia Zhmut, the self-absorbed heroine of the latter story, convulses in lamentations and begs her sons not to go to war, rejecting their duty to the emperor, Dokiia methodically packs her son's sack and sees him off with only a few words of encouragement and a modest request-“Write to me where you are going to be!"-revealing her eagerness to stay connected to her son, now an imperial solder, and, by extension, to follow the ongoing political crisis that has taken him away (62). The actions of the two heroines after their respective sons leave prove even more telling. While Zoia Zhmut loses her sense of reality and collapses unconsciously to the ground, Dokiia kneels gracefully in prayer, asking the two holy mothers of her people, the Mother God and the deceased empress, to look after her mobilized son. Symbolically, Zoia's collapse dramatizes her sorrow and inability to control the lives of her sons. In contrast, Dokiia's prayer frames the scene of Iurko's departure as a ritual of divine sacrifice, as the last trial of Dokiia's loyalty akin to God's test of Abraham's faith, celebrating her sincere devotion to the Habsburgs. The motif of a divine test also allows Kobylians'ka to universalize Dokiia's response to the outbreak of the First World War. Although Kobylians'ka's ironic point, which lies in the fact that personalized and sacral notions and feelings of devotion are what enables Dokiia to come to terms with the modern war, is apparent, the story's final scene foregrounds Dokiia's wholehearted aspirations, which would appear to have been the aspirations of the great majority of Habsburg subjects who, despite radical ethnic, religious, and class differences that separated them internally, united as a single nation in August 1914 in the belief that giving their lives to emperor and country was the only right and honorable thing to do (Botushans'kyi et al. 148-49; Cross 1-10). 
Similar veneration and devotion permeate Kobylians'ka's second war narrative, tellingly called "Sincere Love." The story aims above all to denounce tsarist imperialist politics during Russia's 1914-1915 invasion of Bukovyna through a juxtaposition of emotions displayed by Russian and Austrian soldiers towards their respective monarchs. On the one hand, Kobylians'ka's fictional Russian soldiers express fearful obedience to their despotic tsar, who is constantly "cradled in opaque mist" and who is "no more than a legend that dwells far away behind the walls of guards and armies... in isolated rooms filled with treasure, sorrow, and blood-stained decrees" (12). On the other hand, her Austrian soldiers admire their emperor with unmatched earnestness. The story's most powerful scene takes place when the narrator and his interlocutor, a wounded Russian officer, unintentionally witness an Austrian soldier, an ethnic Ukrainian, praying to a portrait of Franz Joseph. Following Kobylians'ka's damning description of the Russian tsar and his imperialist campaign in Bukovyna, the Austrian soldier's naïve yet sincere appeal to his emperor-"You raised us; we grew up with you; we do not need any foreign tsars. God save you and us!"-could be read as the expression of a genuine appreciation for the economic, political, and cultural achievements Ukrainians attained under Habsburg rule before the outbreak of the First World War (12). This somewhat comical episode provides perhaps Kobylians'ka's most vivid depiction of the pro-Austrian attitude shared by the majority of Western Ukrainians, who, in 1914, as some scholars point out, considered Austria their legitimate homeland and hoped to resolve their national problems within the Habsburg Empire (Magocsi 73, 77-78, Snyder 95-148). In a historical setting where one could simultaneously be a Ukrainian patriot and a loyal Habsburg subject, Kobylians'ka's complex fusion of Austrophilism and anti-tsarist sentiments could be read as an expression of loyalty not only to Austria, but also to the Ukrainophile national project, which hoped before the First World War to inspire fellow Ukrainians in the Russian Empire to join Western Ukrainians in the creation of a new unified Ukrainian entity under the benevolent rule of the Habsburgs (Magocsi 8182; Subtelny 339-44; Karpynets' et al. 39-52).

Fictionalized ACCOUNTS OF COMBAT, 1915-1917

As Kobylians'ka's later war stories demonstrate, the Bukovynian writer maintained pro-Austrian attitudes throughout the early 1920s, yet she began questioning the value of multiple loyalties and hybrid identities once 
the war revealed their inherent contradictions. ${ }^{9}$ In the stories of late 1915-“To Meet Their Fate," "Judas," and "A Letter from a Convicted Soldier to His Wife"-Kobylians'ka consistently brings her Bukovynian characters into contact with German-speaking Austrian authorities or ethnically Ukrainian soldiers of the invading Russian army. The resulting interaction allows her to explore the Ukrainian national project and its possibility under either Austrian or Russian rule. By focusing on the debilitating confusion and consequent inability of her Bukovynian character to understand, let alone to influence, events that radically alter their lives, Kobylians'ka questions the success of Ukraine's national project under any imperial rule, conveying the need for Ukraine's political independence for the first time.

The first text in the 1915-1917 cycle, "To Meet Their Fate," consists of seven brief episodes that comprise an on-the-spot report of the Russian offensive culminating in the capture of Chernivtsi during Russia's second invasion of Bukovyna. Kobylians'ka dramatizes her account by depicting the main battle from the perspective of the peasant girl Nastka and by continually contrasting the innocence of her childhood with the savagery of war. In the opening section, for example, Kobylians'ka situates little Nastka in a lush pastoral setting-war's symbolic 'other'-where she dreams about future love, marriage, and children, as implied by the folk song she hums as she rocks her doll. The following episode, however, disrupts Nastka's play with heavy machine-gun and artillery fire, which "splash blood," "scatter chunks of human flesh," and "bring hell" into Bukovyna's pastoral paradise (383). In the remainder of the story, Kobylians'ka intertwines Nastka's immediate reactions to the war with brief impersonal reports on the Russian army's crossing of the Prut River, the most infamous of which describes the brutal execution of surrendering Cossacks, whom Kobylians'ka loosely describes as "iakyis' viddil rosiis'koho viis'ka, zdebil'shoho tamoshni ukraintsi" [a unit of the Russian army, mostly Ukrainians] (379):

Russian troops... were trying to get to the opposite shore, where Austrian forces... would, most likely, greet them with bullets... They were about to reach the fortified shore... Suddenly, the swimming soldiers threw their rifles into the water, and every one of those who approached the shore

\footnotetext{
${ }^{9}$ While looking for excuses for their defeats, Austrian, Hungarian, and Russian commanders alike often accused Western Ukrainians of treason, which led to almost consistent terrorizing of the Ukrainian population in Galicia and Bukovyna by both warring parties during the war. For further discussion of the repressive nature of Russian and Austro-Hungarian wartime rule in Galicia and Bukovyna, see Botushans'kyi et al. 150-53; Bryndzan et al. 296-301; and Karpynets' et al. 60-67.
} 
raised his arm to signal surrender. They begged; they fought the waves; they cried. Suddenly... hundreds of shots rang out from behind the swimmers' backs - a frightful cry of pain pierced the air... Almost everyone who raised his arm lowered it. The hands rose one last time for a moment. One here... another there... A young head here, and one more with a wild expression of despair there... On the opposite shore, Austrian forces stood as if struck by lightning. Russian troops were shooting their own soldiers in the back. (379-80)

The dry description of a bloody physical reality increases the scene's emotional impact, encouraging readers to visualize its brutality as captured in the telling silence of the bewildered Austrian soldiers. As one recent scholar points out, silence and speechlessness is a recurring theme in literature of the First World War, which indicates much greater loss and pain so often invisible at the time, accentuating simultaneously the incapacity of conventional literary forms, and ultimately of language itself, to represent the life and death of the war (Stevenson 47-53). The following scene, in which Nastka turns up in the midst of the battlefield, proves even more revealing. By recording the little girl's impressions-expressed by cries of anguish, despair, and incomprehension of the ongoing battleKobylians'ka mixes silence with disorder, constructing powerful images of mass slaughter, and thereby exposing the dehumanizing and demeaning nature of war.

The intrinsic value of "To Meet Their Fate" lies not only in its immediacy, but also in its commentary on the "particular absurdity" of Ukraine's position in the First World War. Mobilized to two different imperial armies, Ukrainian soldiers were often forced to kill each other while defending the geopolitical interests of either Austria or Russia, but not Ukraine. ${ }^{10}$ Although Kobylians'ka makes no direct statement, dramatic irony permeates the bitter nickname that Nastka gives the Ukrainian soldier in the Russian army who carries her from the battle. She instantly classifies her savior as "a foe" because of his Russian military uniform, and does not stop calling him so even after her parents welcome the Russian imperial soldier into their house as a fellow Ukrainian. The irony intensifies in the closing episode when the adult characters, the Russian soldier and Nastka's father, discuss the tragic circumstances of their encounter and the grim paradox of their situation, in which, despite their personal affinity, common language, and shared culture, they remain enemies. Previous scholars have written extensively on Kobylians'ka's implicit criticism of the "fratricidal"

\footnotetext{
${ }^{10}$ During the First World War, there were about 3.5 million Ukrainian soldiers fighting in the Russian army and about 250,000 in the Austrian forces. For more information, see Subtelny 340 .
} 
character of the First World War for Ukrainian combatants (Babyshkin 173; Tomashuk 187; Mel'nychuk 120). However, these scholars overlook the writer's comments on how the First World War facilitated the formation of national consciousness among Ukrainian peasants. Although the overall tone is grim, the closing scene optimistically recognizes that, despite the annihilation of the world into which the Russian soldier and Nastka's father were born, the First World War brought the Ukrainian population of the two rivaling empires together, intensifying, as Kobylians'ka hoped in 1915, their shared sense of national identity and ethnic solidarity.

Curiously, "To Meet Their Fate" provides the only case in Kobylians'ka's war narratives in which the writer depicts an encounter between a Western Ukrainian and a Russian Ukrainian in a positive light. All her subsequent accounts of similar scenarios brim with indignation at the harsh treatment by Russian forces, and Ukrainian Cossacks in particular, of Bukovynian civilians during Russian military control of the region, but even more so during the Austrian counteroffensive, which began in May 1915. As Kobylians'ka's biographers suggest, such a radical change in the writer's attitude has a historical explanation. During the first months of the second Russian occupation of Chernivtsi, Kobylians'ka was pleasantly surprised and even flattered by frequent visits from numerous Eastern Ukrainians who came to Bukovyna with the Russian military (Vozniuk 360-61). "As Muslims to Mecca," recalls one of Kobylians'ka's friends, "flowed the Dnieper Ukrainians to pay their respect to the Bukovynian writer" in those days (Korduba 235-36). Naturally, such recognition gave the writer hope for friendly interaction, if not ethnic solidarity, between local Ukrainians and Russian Ukrainians in the tsarist army. Yet the newly established Russian civilian administration terrorized Ukrainian cultural, educational, and religious institutions in the region (Botushans'kyi et al. 150-53; Bryndzan et al. 296-301; Magocsi 25; Subtelny 341-44), quickly undermining, as Kobylians'ka's next story "Judas" testifies, the writer's initial enthusiasm for encounters between Bukovynian and Russian Ukrainians.

The short story "Judas," written only three months after "To Meet Their Fate," vividly registers Kobylians'ka's growing frustration with the Russian military and her decision to rekindle pro-Austrian patriotism among her countrymen. As the story's title implies, "Judas" addresses loyalty, betrayal, and consequent remorse. Like "To Meet Their Fate," the story depicts a fatal encounter between a Bukovynian peasant and a squadron of Russian Cossacks. Although in "Judas" Kobylians'ka does not differentiate Russian soldiers by ethnos, as she does in "To Meet Their Fate," their ability to communicate with the Bukovynian old man suggests that they are at least Russian-speaking, if not Ukrainian-speaking. The Cossacks torture the old 
peasant to extract intelligence that helps them eliminate a unit of Austrian scouts. When the old man learns that his only son was among the slain Austrians, he realizes the tragic consequences of his betrayal, and, like Judas Iscariot, hangs himself out of remorse. His last words before death call his countrymen "to go from house to house and tell people about him, the Judas, and warn them against becoming [traitors] like him" (403). The story's psychological force and didactic message were immediately appreciated-in 1917 alone "Judas" was published three times.

Kobylians'ka's next story, "A Letter from a Convicted Soldier to His Wife," addresses the issue of multiple loyalties by placing a loyal Bukovynian soldier named Vasyl' in a German-speaking environment. Stylized as Vasyl"s five-page letter to his wife, which the character writes after his German-speaking superiors wrongfully accuse him of treason, the story is "unmatched in Ukrainian literature in its powerful depictions of human emotions," as one past critic rightfully observes (Tomashuk 183). However, Kobylians'ka does not focus on Vasyl"s internal turmoil per se, but uses it to dramatize the significance of the war to those who experienced it first hand, be it in the trenches, at military headquarters, or on the home front. For example, while explaining his death sentence, Vasyl' comments at length on his time on the Italian Front, depicting his life in the trenches as a strange combination of tedium and horror, of degradation and brutalization:

In war, a man does not think. He trembles amidst the cannon fire; he is deaf; he is amidst roaring and screaming; he has no control over himself. The only thing he wants is to push forward the power of iron... faster and faster... He is not the same man he was at home. He is... he is... a nothing... [In war,] something other than men is at work. [In war,] iron works and a soldier is nothing, and a man as he was at home is nothing, and hundreds and thousands-all mean nothing. (373-74)

Using simple syntax, parallel constructions, and repetitive negations, Kobylians'ka intensifies Vasyl"s morbid remarks on the dehumanizing experience of war, which, as the character points out, transforms soldiers into insensible automatons, mere extensions of the machinery of war. Here Kobylians'ka joins the broader discussion of the terrifying and demeaning experiences of war, which permeates war literature of her time and stands in sharp and ironic contrast to the heroic images of war circulating before 1914. Fillipo Tommaso Marinetti's futurist glorification of war as "the world's only hygiene" (11-17) and his call to fuse man with machine (210), appear particularly absurd in this context. As Kobylians'ka's above passage suggests, war did indeed merge men with steel and machines, but instead of creating hyper-masculine, powerful bodies, it produced pitiful "cogs in a 
great machine," which, as another commentator of the First World War describes, "sometimes rolled forward, nobody knew where, sometimes rolled backward, nobody knew why" (Toller 82). The underlying drama of Vasyl"s combat experience, as well as Kobylians'ka's overall antiheroic treatment of war or the moral issues it raised, is exacerbated by the soldier's recollections of family and loved ones, of household and wheat fields, of work and religious holidays. By juxtaposing two distinct periods in Vasyl"s life, Kobylians'ka constructs a powerful and universal antiwar statement, linking her personal observations to the general attitude of her contemporaries, most of whom, like Vasyl', divided their lives into a prewar phase of innocence and laughter and a postwar period of hopelessness and loss.

Vasyl"s letter, which blends memories of peaceful life with parting instructions for his wife, also offers a curious social commentary on the intense struggle on the home front, which, as the character foresees, forced women into new social roles after the war. In fact, as the opening account of Vasyl"s nightmare of his wife's multiple suicide attempts suggests, he is more concerned with the future of his family, and, by extension, his people, than with his own fast-approaching death. Similarly, despite the gruesome descriptions of war and its dehumanizing effects, the story is primarily concerned with Ukraine's national revival after the war. Throughout his letter Vasyl' methodically reiterates an appeal to his wife "not to lose her mind" when she hears of his death, something that happens to many soldiers and officers when they see "too much blood and too many severed heads and limbs in battles" (371; similar appeals reappear in the closing episode, 427). As Vasyl' explains, after the war his wife will need all her wits to raise children, to restore life in peacetime, and most importantly, to preserve the memory of modern history's most catastrophic disaster. We cannot help but notice the direct reference to Kobylians'ka's earlier views on the pivotal role played by women in biological and cultural regeneration of a nation, a role whose significance becomes particularly evident during the war. ${ }^{11}$

As in previous stories, Kobylians'ka intertwines universal statements with commentary of national significance, embedding both in Vasyl"s reflections on the ineffectiveness of his mother tongue, Ukrainian, during the Austrian court-martial. Previous critics tend to read Vasyl"s execution as a criticism on Kobylians'ka's part of the Austrian authorities and their unjust persecution of thousands of Ukrainian peasants and low-ranking soldiers, whom they typically considered Russian spies during the First

\footnotetext{
${ }^{11}$ For further discussion on Kobylians'ka's views on women's role in biological and cultural regeneration of a nation, see Ladygina 44-45.
} 
World War (Babyshkin 171; Tomashuk 181-82; Komyshanchenko 39-40; Mel'nychuk 116-17). However, several textual and intertextual details suggest that such a reading is too narrow. For Example, Kobylians'ka's other stories-"Judas" of 1915 and "Tuha" ("Anguish") of 1932, to name but two-claim that some Bukovynian Ukrainians deserved punishment for treason and desertion, but were pardoned once they explained their motives and expressed sincere regret for their misconduct. These stories suggest that the Austrian government strove, and often succeeded, in remaining as fair and humane as before the war, when its judicial system was ranked among the most just in the world. Kobylians'ka promotes a similar idea in her other story, "Voiennyi akord" ("A Chord of War," 1932), in which a former captain and a court-martial judge of the Austrian imperial army confesses his remorse for the first death sentences he endorsed during the war only because he had neither the time nor the means to continue investigation. In light of this later story, Vasyl' appears not so much a victim of the Austrian court-martial, which must be "inexorable and quick like a machine gun" during wartime (374), but as a victim of the same social and political disintegration that undermined the Austrian government and toppled the Habsburg Empire. In this way, Kobylians'ka symbolically embeds a Ukrainian national cause in a broader geopolitical context.

Previous critics also disregard the fact that Vasyl"s unjust persecution forces him to reevaluate his own role in the ongoing conflict and to ponder the overall contribution of Ukrainians to Austrian society (Babyshkin 171; Tomashuk 181-82; Komyshanchenko 39-40; Mel'nychuk 116-17; Pavlyshyn 244-45). As suggested in Vasyl"s reflections, the war not only breaks, but also transforms him. In addition to re-forging his understanding of ethnic and national identity, the war redefines his views on loyalty and the motherland-a reflection on those Western Ukrainians, whose less conciliatory attitudes towards Austrian rule by the end of the war led them to the conclusion that the Ukrainian national project was ultimately incompatible with Austria's imperial interests. ${ }^{12}$ Several months later, in the allegorical short story "Snyt'sia" ("A Dream," 1922), Kobylians'ka explores the notion of Ukraine's self-recognition further, demonstrating that, despite its pain, the process allows for the rediscovery of the virtues necessary for Ukrainian national life and promises to put them into practice anew. In "A Dream," Kobylians'ka registers the profound transformation of Western Ukrainian society during the war, and offers her reflection on the

\footnotetext{
12 Ievhen Petrushevych (1863-1940) was one of the first Western Ukrainian political leaders to insist on Ukraine's autonomy and demand Galicia's separation from the Austrian empire long before the official dissolution of the empire. See Motyl 26.
} 
nascent vision of the postwar world held by Western Ukrainians, both combatants and civilians. Neither group in the story has a clear perception of this future; however, both firmly express hope for Ukraine's independence, as implied in the ultimate goal that the old men set for their offspring- "to leave their trace on their own land" (411).

\section{POSTWAR REVISIONS}

Kobylians'ka's first postwar novelette, "Vasylka" (1922), continues to explore the notion of national self-recognition and rediscovery, embedding it in the historical and social context of the early 1920s. The title character, a Bukovynian peasant woman, tells the story of how she hid a fugitive prisoner of war, a Ukrainian soldier in the Austrian army Ivan Rotenchuk, from Russian troops during Russia's third occupation of Bukovyna. Despite obvious ties to Kobylians'ka's earlier war narratives, "Vasylka” constitutes a qualitatively different text, focusing on memory, recovery, and the transition to a new future. Stylistically, "Vasylka" also deviates from Kobylians'ka's previous war narratives. Although the story takes place during the Brusilov offensive, the Russian Empire's greatest feat of arms during the First World War and one of the most lethal offensives in world history, Kobylians'ka offers no direct descriptions of carnage, which characterize her 1915-1917 stories. $^{13}$ Instead, she uses an elaborate and highly condensed allegory to evoke the apocalyptic nature of the First World War, displaced into an eerie dream, or better a nightmare, which Vasylka's husband Maksym sees long before the war breaks out:

[Maksym] walks as if in his own field, looking for its borders amid other landowners' fields but cannot find them... Instead he catches a glimpse and what does he see? From that far-off place where the earth and the sky usually meet as if greeting each other at daybreak, massive clouds of smoke are emerging quickly, one after another... Some slither like black vipers up into the sky, and others coil over the fields like snakes. What could it be? If it does not turn out for good, it will bring about something frenzied... And what do you know-here it comes. A white, elongated horse emerges from the smoke. The horse is without a saddle and its neck is stretched for six hands. It is terribly emaciated. As if from a bullet wound, blood gushes from between its ribs. With its mouth wide open, the horse gallops feverishly, neighing mournfully and menacingly. Clouds of smoke rise behind it. The field is no longer a field, not a green wave of new sprouts, not God's freshly plowed land, but some kind of wasted plain covered with dried lumps of

\footnotetext{
${ }^{13}$ For a comprehensive discussion of the Brusilov offensive and its role in the First World War, see Afflerbach 256-64.
} 
turned up soil, one larger than the other, and trenches of some sort. Is it a desert? Or what else could it be? (16)

Later in the story, Kobylians'ka links Maksym's dream to the First World War by using the same description of plundered fields and wounded horses-images that have come to epitomize the senseless destruction of the First World War-to report its outbreak:

The war broke out... The earth was ripped apart, turned over, and flooded with blood... Human, animal, and cannon wailing filled the air. Wounded wandered to and fro. The white, black, and brown ghosts of horses fell heavily to the ground. (20)

When taken together, these two episodes arguably offer Kobylians'ka's most aestheticized representation of the war, a 'mad dream' that destroyed millions of human lives and turned Europe into a wasteland. Vasylka's graphic narration of Maksym's death in an explosion, which he supervised while working on a railroad construction in Canada, is also complicit with the mutilation and dismemberment of the battlefield, and likewise serves as a displacement of the violent war experience before which mind and articulacy inevitably renege. Like tropes of silence and incoherent speech, which figure in Kobylians'ka's 1915-1917 stories, both allegorical episodes in "Vasylka"-Maksym's nightmare and the story of his death-render Western rationality and conventional forms of communication dysfunctional. At the same time, they also communicate a new tendency in Kobylians'ka's treatment of the war-an unremitting desire to come to terms with the traumatic experiences of the recent past and to transition to a new future free of fear, disillusionment, and regret.

To amplify the critical distance between the reader and the traumatic events of the First World War, and thus to facilitate an effective reassessment of the war and its aftermath, Kobylians'ka uses elements of skaz, another stylistic device that sets "Vasylka" apart from her earlier war narratives. The Bukovynian writer structures the story's second part as Vasylka's dialogic monologue, much of which takes the form of chaotically recreated dialogue exchanges between the heroine and different Russian, Austrian, and Bukovynian characters. Using distinctive colloquialisms, and, on occasion, forms taken from vernacular dialect, the writer forges an alternate style purged of inflated language and conventional stereotypes in order to communicate Vasylka's individual war experience and to locate it in the broader historical context. The heroine's verbal inventiveness and resourceful manipulation of language not only demonstrate her impressive ability to adapt, but also highlight Kobylians'ka's own experimentation in a narrative that explores the limits of language in expressing the unutterable 
trauma of war. Similarly, Vasylka's anecdotes about how she outsmarted Russian soldiers, local spies, and fellow villagers, as well as the overall naïveté and clumsiness of her skaz narration, ultimately have a double function. Her humor serves not only as defense mechanism, but also as a means for Kobylians'ka to emphasize her heroine's profound emotional turmoil. In one of the most revealing examples of her double-edged humor, Vasylka recalls a dramatic tragicomedy she staged, which combined seduction, self-pity, and flattery in the attempt to avoid persecution after the Russian soldiers found Ivan in her house:

Gentlemen! For seven years, I have been living without a husband. It's been four, since I last heard from him. I think he is already dead. And I love this man, and he loves me. He doesn't have a wife and we could have gotten married. And he also used to tell me, "I wish the Muscovites stayed here longer because when our Austrians return they'll either shoot me or send me back into the trenches, and you wouldn't have me anyway. The Muscovites are very kind people. If they take me to Russia, it might be even better for me. They are kind people." (30)

Here Vasylka openly admits her frustrated sex life while slyly hinting that only the Russian troops can help her with this frustration, making the Russian officers giggle. However, the sharp juxtaposition between the humorous mode of narration and the grave circumstances effectively communicates the heroine's extreme distress. The overall flatness of Vasylka's story and its focus on mere surface events also betray tremendous internal pressures, inviting readers to probe the heroine's immediacy of speech more deeply and to reconstruct her inner thoughts and feelings.

Kobylians'ka's use of allegory and skaz, which often entail cultural and social criticism, along with the turbulent historical context of the story's creation, suggests the possibility of embedded political commentary. For example, Vasylka's relationship with the fugitive Ivan and the interactions of the two Ukrainian characters with Russian soldiers can be viewed as an allegorical reference to the unified effort of Ukrainophile forces to resist Russia's occupation during the First World War, as well as during Ukraine's struggle against the Bolsheviks in 1918-1922. Curiously, the collective image of Russian soldiers is identified throughout the story with the popular ethnonym Moskali (the Muscovites), which acquired new ideological connotations in the early 1920s. During the nineteenth century, the word Moskali, typically, designated a soldier in the Russian imperial army and carried mild negative national connotations. ${ }^{14}$ However, after the

${ }^{14}$ See, for example, Grinchenko 2: 447. 
Bolshevik Revolution, it became an ethnic slur and a derogatory epithet for Russian Bolsheviks and all pro-Moscow opponents of Ukraine's political independence..$^{15}$ Kobylians'ka's choice of the word Moskali, which appears nowhere in her earlier fiction, to designate Russian soldiers in the 1922 story, thus indicates a shift in her attitude towards Russians. If in 19151917 Kobylians'ka rarely described Russian soldiers in exclusively negative terms, often justifying their cruelty in combat or ameliorating it with their humanity, then in 1922 she depicts Russians as a gang of simpletons, rapists, and thieves, highlighting their lack of loyalty and national pride.16 As one Russian spy openly states in a conversation with Vasylka, Russian troops "would sell Russia for two kopecks" (31). Kobylians'ka's pejorative representations of Russian troops, and by extension their government, suggest that in 1922 the Bukovynian writer, like many Western Ukrainian patriots, had no illusions as to Ukraine's political future under the new Russian government.

In turn, the emasculated image of the fugitive Ukrainian soldier Ivan Rotenchuk suggests that Kobylians'ka also held a realistic view of the effectiveness of the Ukrainian army and political institutions it represented in 1922. Her implied parodic commentary becomes most sardonic when Vasylka cross-dresses Ivan as a woman. Once the heroine costumes him in "her shirt and her skirt, makes him a head-dress out of her scarf, cloaks him in two sheepskin coats, and gives him her small boots" (23), Ivan loses the last traces of his already fragile manhood, becoming the object rather than the subject of ongoing historical events. His symbolic castration is completed shortly afterwards, when two Russian soldiers attempt to rape the cross-dressed soldier, mistaking him for a woman. We can easily view the representation of a Ukrainian soldier-he is a demoralized, somewhat cowardly, and helpless product of Ukraine's psychological unpreparedness for the First World War and, by implication, for the consequent struggle for national liberation-as Kobylians'ka contribution to the revanchist criticism of Ukraine's political weakness in the wake of the First World

15 The Manifesto of the Organization of Ukrainian Nationalists, written in December of 1940, which describes the USSR as "the Muscovite prison of nations," effectively conveys the new ideological connotation that "Muscovite" and "Muscovy" acquire after the Bolshevik Revolution. See excerpts in Lindheim and Luckyj 291, 294. Similar connotations underline Ievhen Onats'kyi's entry "Moskali," one of the most extensive and most passionate encyclopedic entries to date. See Onats'kyi K: 104143.

${ }^{16}$ Kobylians'ka's first pejorative description of Russian troops appears in her 1918 letter to Stefaniia Sadovs'ka, where the Bukovynian writer spitefully calls Russian soldiers "prokliati chorty-vorohy" [cursed, demonic enemy]. See Komyshanchenko 5: 629 . 
War-a theme, Kobylians'ka further develops in her last novel Apostol cherni (Apostle of the Rabble, 1936). ${ }^{17}$

Like many other cultural and political commentators of the time, Kobylians'ka combined her critique of Ukraine's political ineffectiveness and alternative to post-1918 Ukraine in the image of Vasylka. However, Kobylians'ka's 1922 vision differs substantially from the flamboyant images of a new Ukraine forged in the mid 1920s by her radical nationalist compatriots. Leading intellectuals of the interwar Ukrainian nationalist movement-Dmytro Dontsov and Ievhen Malaniuk, for example-glorify aggressive masculinity and military action, using female characters only to castigate Ukraine's political immaturity in the hopes of bolstering Ukraine's interwar state-building efforts with a new warrior ethos. On the contrary, Kobylians'ka conveys her opinion of Ukraine's current political situation through a robust and resourceful female character. When compared either to the heroines violated by Moskali and canonized by the leading nineteenth-century Ukrainian poet Taras Shevchenko or to their shocking adaptations by Ievhen Malaniuk, who often depicts Ukraine as the whore of khans, tsars, and sultans, Kobylians'ka's heroine has clearly positive symbolic connotations. ${ }^{18}$

Even the heroine's name, a derivative of the masculine Vasyl', suggests that Vasylka embodies the strong, proactive, and self-sufficient woman who the unfortunate hero of "A Letter from a Convicted Soldier to His Wife" implores his wife to be. In the first part of "Vasylka," Kobylians'ka emphasizes the profound transformation in character that the heroine undergoes once her husband Maksym goes to work in Canada for several years before the war, leaving her alone with two small children. Despite the difficulty of farm work, Vasylka quickly discovers that skill and diligence are as serviceable as strength and the traditionally gendered division of household tasks is mere convention. During the six years of independently running her household, Vasylka increases her livestock, buys new shares of land, and learns how to negotiate with bankers, market traders, and

17 For a discussion on the nationalist critics of Ukraine's interwar political weakness, see Shkandrij 243-249. For a discussion of Kobylians'ka's critique of the male political leadership of the 1920s and 1930s in her last novel, see Pavlyshyn 251-79.

${ }^{18}$ From the mid nineteenth century onward, Ukrainian writers religiously employed images of docile and violated women to symbolize their oppressed nation. In the Ukrainian paradigm, this tradition derives from folk songs and becomes canonized in Shevchenko's poetry, where Ukraine is often represented through images of orphans, lovelorn girls, or simply poor folks suffering at the hand of the well-off evildoers. See Grabowicz 61. For a sample of Malaniuk's allegorical representations of Ukraine, see "Z chornoi Ellady" and "Lezhysh, rozpusto, na rozputti" in Malaniuk 99, 104-05. 
government officials, gradually transforming "from a slim, young, and girlish-looking woman" into "a serious, robust, and hard-working mistress of the farmstead" (18-19). Vasylka's mature image resembles another unusual peasant woman in Kobylians'ka's 1897 short story "Nekul'turna" ("Uncultured"). Like the 1897 heroine Paraska, Vasylka is not only selfsufficient, hardworking, full of energy, and determined, but also clever, outspoken and exceptionally resourceful in protecting her interests. The narrator acknowledges Vasylka's assertiveness and authority by describing her scrutinizing eyes and piercing gaze, which demand recognition and "make one ill at ease" (18-19), granting the heroine the symbolic agency of someone who looks and not someone who is looked at. However, Vasylka is more than a post-war revision of Paraska. Although Vasylka, like Kobylians'ka's 1897 heroine, has no formal education, her systematic exposure to urban culture helps her to understand better her social, cultural, and historical context, as well as to develop a strong sense of belonging to broader communities, both local and imperial. Consequently, while Paraska remains, owing to her childlike naïveté and blissful ignorance, the subject of a dreadful and aimless existence, tellingly captured in her nearly fatal night wandering through the woods in search of the magic devil's mill (323-55), Vasylka courageously stands up to the challenges of the First World War, demonstrating heroism so exceptional that it places her on an equal, if not superior, footing with her cultured contemporaries. Vasylka's physical, spiritual, and cognitive transformation suggests that Ukraine emerged from the first World War as a radically new entity with a fervent anti-Moscow sentiment, which along with its pronounced Austrophilism can be interpreted as a clearly defined national goal-a Ukrainian state both independent of Russia and with a strong proEuropean orientation. ${ }^{19}$

However, the story's ending is redolent of drab domestic details and far from optimistic. Kobylians'ka explicitly shows that although Ukraine survived the war, its toll was staggering with the country's people emotionally crippled, and incapable of dissociating themselves from the tragic past. The only hope the writer leaves for Vasylka's postwar recovery, and, by extension, for Ukraine's political revival, lies in the character of her teenage son Dmytryk and his determination to wipe away all tears from his mother's eyes-a vivid personification of the new postwar generation of Ukrainians and their commitment to the national cause. Dmytryk's resolution suggests that in 1922 Kobylians'ka realized that overcoming the full effects of the war would occupy not only the generation that survived it,

\footnotetext{
${ }^{19}$ For further discussion on Ukraine's interwar national project, see Motyl.
} 
but also many future generations. Kobylians'ka's 1923 story "Ziishov z rozumu" ("A Mad Man"), in which a fatally wounded Ukrainian officer prophesies Ukraine's political resurrection, promotes similar ideas, asserting that despite the destruction, the First World War helped to crystalize the previously inchoate national aspirations for Ukraine's political independence-a goal that defined postwar Ukrainian politics.

\section{CONCLUSION}

A close reading of Kobylians'ka's stories of the First World War decisively demonstrates that for the Bukovynian writer, as for many of her contemporaries across Europe and beyond, the catastrophic events of 1914-1918 functioned as the catalyst for a thorough revision of her prewar beliefs. Although they focus predominantly on the transformations of the Bukovynian character, Kobylians'ka's war narratives not only illustrate Ukraine's unique position in the First World War, but also redefine key universal notions of loyalty, duty, honor, political agency, and artistic expression, reshaping the traditional understanding of Europe's first shocking experience with modern mass warfare and the role of the individual in it. The striking chronological shifts in Kobylians'ka's representations of the Bukovynian home front, along with her creative assessment of the Austrian and Russian treatment of Western Ukrainians during different stages of the First World War, expose anew fatal political weaknesses in Europe's old imperial order and provide a better understanding of why Ukrainians, like other so-called non-historic ethnic groups without a state of their own to protect their specific interests, began to pursue their national goals more aggressively as the war progressed. ${ }^{20}$ Kobylians'ka's representations of Bukovynian peasant women also illustrate that women's collective experience of the First World War was not confined to that of Western European middle-class women, thus opening a fresh perspective on women's intense struggle for survival in war zones and their unique role in preserving the memory of one of the greatest catastrophes in modern history. The variety of ways in which Kobylians'ka articulated her encounter with war demonstrates, in turn, that the Bukovynian writer, like many other war commentators, quickly discovered the inadequacy of traditional literary conventions in capturing the unspeakable horror of war, and ventured to search for alternative

\footnotetext{
${ }^{20}$ Miroslav Hroch, a leading historian of nationalism in Eastern Europe, delineates the nonhistorical, or nondominant, ethnic groups as nations that, contrary to the nation-states, lacked their own nobility, possessed no state, and had a sparse or interrupted literary tradition in their own language. See Hroch xiii.
} 
rhetorical means of expression. Although Kobylians'ka's experimentations with language reveal many points of contact with other authors who wrote about the First World War, the stylistic idiosyncrasies of her prose, particularly her use of skaz and tragicomedy, as well as its specific thematic and ideological aspects, highlight a wide spectrum of reactions among the general European population, a spectrum whose plurality remains far from complete. Ol'ha Kobylians'ka's war writings thus deserve a place in the expanding canon of war literature, not only as legitimate studies of national attitudes, cultural awakening, and redefinition of the Western Ukrainian self, but also as valuable cultural documents that help us to recreate and to reimagine the collective experience of 1914-1918 and force us to reconsider the enormous social, political, economic, and cultural repercussions of war.

\section{Works Cited}

Afflerbach, Holger. "The Eastern Front." The Cambridge History of the First World War. Ed. Jay Winter. Vol. 1. Cambridge: Cambridge UP, 2014. 256-264. Print.

Babyshkin, Oleh. Ol'ha Kobylians'ka: Narys pro zhyttia i tvorchist'. Lviv: Knyzhkovozhurnal'ne vydavnytstvo, 1963. Print.

Botushans'kyi, Vasyl', Svitlana Bilenkova, and Oleksandr Dobrozhans'kyi, eds. Chernivtsi: Istoriia i suchasnist'. Chernivtsi: Zelena Bukovyna, 2009. Print.

Bryndzan, Taras, Denys Kvitkovs'kyi, and Vasyl' Zhukovs'kyi, eds. Bukovyna: Ii mynule i suchasne. Paris, Philadelphia, Detroit: Zelena Bukovyna, 1956. 296301. Print.

Cross, Tim, ed. Introduction. An International Anthology of Writers, Poets, and Playwrights: The Lost Voices of World War I. Iowa City: U of Iowa P, 1983. 1-14. Print.

Demchenko, Iryna. Osoblyvosti poetyky Ol'hy Kobylians'koi. Kyiv: “Tvim-inter,” 2001. Print.

Freud, Sigmund. Group Psychology and the Analysis of the Ego. New York: Norton and Company, 1989. Print.

Grabowicz, George. The Poet as Mythmaker: A Study of Symbolic Meaning in Taras Shevchenko. Cambridge: Harvard UP, 1982. Print.

Grinchenko, Borys ed. Slovar' ukrainskogo iazyka. Kyiv: Druk aktsiinoho tovarystvava Korchaka-Novyts'koho, 1907-1909. Print.

Himka, John-Paul. Religion and Nationality in Western Ukraine: The Greek Catholic Church and the Ruthenian National Movement in Galicia, 1867- 1900. Montreal: McGill-Queen's UP, 1999. Print.

Hroch, Miroslav. Social Preconditions of National Revival in Eastern Europe: A Comparative Analysis of the Social Composition of Patriotic Groups Among the Smaller European Nations. New York: Columbia UP, 1985. Print.

Hrytsai, Ostap, ed. Ale Hospod' movchyt' i inshi opovidannia. Chernivtsi: Vesna, 1927. Print. 
Karpynets', Ivan, Feodosii Steblii, Bohdan Iakymovych, eds. Halychyna: Viis'kova istoria, 1914-1921. Lviv: Vydavnychyi dim "Panorama," 2005. Print.

Kobylians'ka, Ol'ha. "Iuda." Komyshanchenko 4: 391-405. Print.

---. "Lisova maty." Hrytsai. 54-62. Print.

---. "Lyst zasudzhenoho voiaka do svoiei zhinky." Komyshanchenko 4: 370-75. Print.

---. "Na zustrich doli." Komyshanchenko 4: 376-90. Print.

---. "Nekul'turna." Komyshanchenko 2: 323-55. Print.

---. "Shchyra liubov." Viis'kovyi lystok Shtrifliera 17 (1916): 12-13. Print.

--.. "Snyt'sia." Komyshanchenko 4: 406-12. Print.

---. "Vasylka." Hrytsai. 16-36. Print.

---. "Vovchykha." Komyshanchenko 4: 419-82. Print.

---. "Ziishov z rozumu." Komyshanchenko 4: 413-18. Print.

Komyshanchenko, Maksym, ed. Ol'ha Kobylians'ka: Tvory v p"iaty tomakh. Kyiv: Derzhavne vydavnytstvo khudozhn'oi literatury, 1962-1963. Print.

Korduba, Ievhen. "Moi spomyny." In Ol'ha Kobylians'ka: Al'manakh u pam"iatku ii sorokalitn'oi pys'mennyts'koi diial'nosti, 1887-1927. Ed. Lev Kohut. Chernivtsi: Nakladom iuvileinoho komitetu v Chernivtsiakh, 1928. 233-36. Print.

Ladygina, Yuliya. "Narrating the Self in the Mass Age: Ol'ha Kobylians'ka in the European Fin-de-Siècle and Its Aftermath, 1886-1936." PQDT Database, 2013. Print.

Lesyn, Vasyl', Ivan Slyn'ko, and Ivan Cherednychenko, eds. Ol'ha Kobylians'ka: statti i materialy. Chernivtsi: Vydavnytstvo chernivets'koho natsional'noho universytetu, 1958. Print.

Lindheim, Ralph, and George Luckyj, eds. Towards an Intellectual History of Ukraine: An Anthology of Ukrainian Thought from 1710-1995. Toronto: U of Toronto P, 1996. Print.

Lyzanivs'kyi, Ivan. Ol'ha Kobylians'ka: Tvory v dev"iaty tomakh. Kharkiv: Rukh, 19271929. Print.

Magocsi, Paul Robert. The Roots of Ukrainian Nationalism. Toronto: U of Toronto P, 2002. Print.

Malaniuk, Ievhen. Zemna Madonna: Vybrane. Bratislava: Slovats'ke pedahohichne vydannia, 1991. Print.

Marinetti, Fillipo Tommaso. Critical Writings. Trans. Doug Thompson. Ed. Günter Berghaus. New York: Farrar, Straus and Giroux, 2006. Print.

Mel'nychuk, Iaroslava. Ol'ha Kobylian'ska v ostannii period tvorchosti, vid 1914 roku. Chernivtsi: Bukrek, 2006. Print.

Motyl, Alexander. The Turn to the Right: The Ideological Origins and Development of Ukrainian Nationalism, 1919-1929 New York: Columbia UP, 1980. Print.

Onats'kyi, Ievhen, ed. Ukrains'ka mala entsyklopediia. Buenos-Aires: Administratsiia UAPC v Argentyni, 1959. Print.

Pavlyshyn, Marko. Ol'ha Kobylians'ka: Prochytannia. Kyiv: Akta, 2008. Print.

Pohrebennyk, Fedir. Forward. "Ol'ha Kobylians'ka." Ol'ha Kobylians'ka: Tvory v dvokh tomakh. Ed. Fedir Pohrebennyk. Kyiv: Dnipro, 1988. 5-20. Print.

Toller, Ernst. I Was a German. Trans. Edward Crankshaw. London: John Lane the Bodlet Head LTD, [1934]. Print.

Tomashuk, Nikifor. Ol'ha Kobylians'ka: Zhyttia i tvorchist'. Kyiv: Dnipro, 1969. Print. 
Shkandrij, Myroslav. Russian and Ukraine: Literature and Discourse of Empire from Napoleonic to Postcolonial Times. Montreal: McGill-Queen's UP, 2001. Print.

Snyder, Timothy. The Red Prince: The Secrete Lives of a Habsburg Archduke. New York: Basic Books, 2010. Print.

Stevenson, Randall. Literature and the Great War, 1914-1918. Oxford: Oxford UP, 2013. Print.

Subtelny, Orest. Ukraine: A History. Toronto: U of Toronto P, 1988. Print.

Vasylenko, V. "V zavorozhenim kruzi." Krytyka 1 (1928): 68-85.

Vozniuk, Volodymyr. Bukovyns'ki adresy Ol'hy Kobylians'koi. Chernivtsi: Knyhy XXI, 2006. Print. 
(c) 2015 East/West: Journal of Ukrainian Studies (ewjus.com) ISSN 2292-7956 Volume II, No. 2 (2015) 